\title{
Tourist satisfaction of rural services and facilities in Neyshabour
}

\author{
Zahra Mehmannavaz ${ }^{1}$, Mohammad Ali Ahmadiyan ${ }^{2}$, Katayoon Alizadeh $^{3}$, \\ Hamid Jafari ${ }^{4}$ \\ ${ }^{1-}$ PhD student, Department of Geography, Mashhad branch, Islamic Azad University, Mashhad, Iran \\ 2, 3, 4-Associate Professor, Department of Geography, Mashhad branch, Islamic Azad University, Mashhad, Iran
}

\begin{abstract}
Level of tourists' satisfaction, discovering factorsaffecting their satisfaction and efforts to attract their satisfaction are among the important factors in attracting tourists and developing tourism In an area. This study is a survey and has aimed to determine the level of tourists' satisfaction of rural facilities and services in Neyshabour. It had a sample size of 384 Tourists. Findings show that tourists' satisfaction with facilities and services available in rural areas is low; however, due to high tourist attractions willingness to travel to rural areas is high which indicates the need for more attention to the development of tourism facilities and services.
\end{abstract}

Keywords: Rural tourism, satisfaction, Facilities and services, Neyshabour

\section{Introduction}

With respect to global experiences, rural tourism can have considerable economic and social benefits for the rural areas through increasing income and improving infrastructure particularly in less developed areas. That is why in many developed countries rural tourism is in the country's program as a separate section or in the framework of the country's general program(Rezvani, 2:1390). Iran as a developing country whose main source of income, oil, will soon end, needs to use all its resources and capabilities to replace the oil reserves and create a sustainable and thoroughdevelopment. Here the tourism industry is noticed, whichaccording to statistics and figuresthe worldtourism organization released in The New Millennium is the largest source of Income (Madhoushi, 25:1382).

In the present century,the various features of transportation industry have removed communication limitations among different human communities and thus Tourism has been raised as a basic and important issue in humanlife. This service area has prepared rural areas for economic, social, cultural, etc. development (Heydari Chyaneh, 1383: 77).

Most countries must provide the necessary infrastructure according to the cultural and geographical features to succeed in attracting tourists, since having the required facilities isthe first step in attracting and keeping tourists.Hence knowing the areain terms ofthese factors preparesthe background to get to knowthe area's regional tourism and the damages its development can cause, to meet the tourists' expectations sothat they are satisfied with the destination (Ibrahimpour and Roshandel, 1390: 22).

Neyshabour rural tourism with its capacities and strong capabilities can be one of the foregrounds for social, cultural and economic development in rural regions and even urban areas. This paper seeks to examine the amount of tourists' satisfaction of rural tourism facilities and services of Neyshabour. The purposes of this study are:

$\checkmark$ Examining the relationship between tourist satisfaction andrural facilities and services in Neyshabour

$\checkmark$ Finding out tourists' opinion on facilities and services in rural areas of Neyshabour.

Therefore, this study seeks to answers the questions below:

$>$ What is the relationship between rural facilities and tourist satisfaction in theNeyshabour?

$>$ What are tourists' opinionsabout facilities and services in rural areas ofNeyshabour?

Hypotheses is:There is a significant relationship between rural facilities and services and tourists' satisfaction in Neyshabour.

\section{Theoretical Foundations}

Rural tourism is a kind of tourism whichincludes activities in the rural areas and areas surrounding them. This includes values and consequences in environmental, social and economic aspects ( Seteriades, 2002: $615)$.

Distinct groups of tourists have different tastes and expectations (Clark and Dieleman, 1966: 23). Knowingpeople's tastes improves the design of places and spaces (Kitchin et. al, 2002: 35). Accessing residential infrastructure such as hotels, motels, and other accommodation and catering units, travel offices, the number of tourism companies and tourist-attractive areas play an important role in the tourists' satisfaction (Shoaei and MousaVand, 1390: 23). 
Satisfaction can be considered the feeling when somebody achieves a dream. Satisfaction requires asatisfier which is the prize orany condition or foreign state that will lead to the fulfillment or satisfaction. From the point of view of sociologysatisfaction leads to increase of administrative systems' legitimacy and stability andin terms of management it is one of the basic and inevitable principles of quality management science perspective, and is an equally important criterion inthe context of business excellence models (Firouz Abadi and Imani Jajarmi, 1391: 91-61).

\subsection{Tourism definition}

\section{Literature Review}

Up to now tourism has been under study and discussion from view of different science like economics, sociology, and geography and based on any views has raised various definitions that Rezvani (1996) accumulates the collection of them under title as geography and tourism industry. For example Artobruman has defined tourism the fallowing: "tourism contains travels collection that it performs due to rest, fun, experience and other vocational activities or due to take part in the specific ceremonies and it is temporary and passing that tourist don't exist in her/himself address. It is clear that persons, who perform permanent vocational travel between her/himself address and place of work, don't include to this definition” ( Rezvani , 1996 ) .

From view of sociology, tourism is a relations collection that person creates with others in her/himself temporary address. According to Honziker-krapph, tourism is relation collection that it creates from travel and residence of one nonnative person without having permanent address and job. The definition was acceptable by international council of science experts in tourism for times. According to Morgan Rout, tourism in literal meaning is travel of persons that go away from themselves address temporary until they granted vital, cultural and personal needs in form of a consumer of economic and cultural goods. In competitions that tourism international union held to gain general definition for tourism, the fallowing definition is selected. According to this definition "tourism is collection of changing place of persons and actions that conclude from it. The changing caused by come true demands that they force person to movement and there are potentially in any person by different intensity and weakness.

Today tourism phenomena is more than simple phenomena of visit and return visit and obtain specific importance that it is called as a huge, producer and main industry. In many advanced countries and some of countries exist many attractions of historical, cultural, natural and facilities of tourism attracted (Tulaii, 2007).

The grate portion of nation income supplies with tourism development. It isn't UN due that most of countries, especially countries that have more historical, cultural and natural attractions, try to obtain more options in absorption of different countries tourists and get foreign exchange income for themselves by creating and development of necessary touristic facilities.

On the other hand, tourist is foreign person for travel, tourism, and sports .The residence is not less than 24 hours and not more than 2 months. According to a Committee on 22 January 1937, the following definition for tourists can be justified: a person who travels to a country for 24 hours or more and usually has the right to stay there (Moradi, 2007: 9 -14).

\subsection{Classification of Tourism}

Classification of tourism is the important tool to understand the capacity of the country according to get the competitive advantages by focusing in some types of them. According to World Tourism Organization (UNWTO) in 1993 defined the word of tourism as the following: "travel to and stay in places outside their usual environment for more than twenty-four (24) hours and not more than one consecutive year for leisure, business and other purposes not related to the exercise of an activity remunerated from within the place visited."

United Nations In 1994 classified three forms of tourism in its Recommendations on Tourism Statistics:

- Domestic tourism, which involving residents of a given country traveling only within this Country.

- Inbound tourism, involving non-residents of a given country that traveling within this country.

- Outbound tourism, which involving residents of a country traveling to the other countries.

In June 1991, the International conference held by organizing the World Tourism Organization and government of Canada about the travel and tourism statistics in Ottawa. Their defining words, phrases and their classification decisions were taken which are as below:

- Tourism, is the things or acts that the person who travelled doing in a place outside of his/her normal environment, the traveling take long not more than a year and its purpose is to fun, business or other activities.

- Traveler or tourist (overnight visitor) is someone who spent at least a night in public or private residence at the site visit.

- Same day visitor or one day tourist is someone who is staying in a place but not for the night.

- Based on the above classification, the governments must focus their forces to promote international tourism by making their strategies base on their capacity to attract travelers. 


\subsection{History of tourism industry in Iran}

Tourism shaped in Iran from the second decade of present century and the first time in 1994 year was established office named "attraction of foreign visitors and publicities office" in interior ministry and was assigned to this office do works related to tourism. "Iran tourism association" established for supplying comfort and facilitating travel of tourists in this same year. The association, that record officially in MAY /1939 year, organized different tour for tourists visit. Attraction of visitors office was changed its name to "tourism supreme council" in September of 1942 year. Tourism supreme council was changed to tourism affairs office and was centered in the interior ministry in1333 year. From the office actions during 1955-1959 years, can indicate to doing some services of sub structural and compilation of laws and rules related to tourism as "entry law and residence of foreign national".

An organization named "attraction of visitors organization" depended on premiership was established on April /1964. The organization main purpose was presentation of country back ground, encouragement of interior and foreign tourists to traveled and visited ancient relics and natural views and created necessary concentration and coordination in affaires. Attraction visitors organization was combined on information ministry and made new ministry named "information and tourism ministry" in Jun /1975. To fallowing of Islamic revolution victory, information and tourism ministry at firs changed name to ministry of national guidance and then to ministry of Islamic guidance and tourism assistance district of this ministry undertook tourism affairs supervision. Iranology and tourism office established for planning of tourism industry, educating of tourism charges, classification, supervision and evaluation of plants, establishment of international relationship with institutions and organs of foreign tourism and take part in meetings, tourism exhibitions and international gatherings. After a while this office according to ratified in 21/December /1980 of Islamic revolution council was changed its name to "organization of Iranology and tourism centers" that was made by combining four state companies as plants stocks of Iran tourism company, stocks of Iran visiting company, stocks of Iran homes centers company and stocks company of tourism centers tourism for winter sports (Moddaresi, 2000). Despite the fact that government hadn't clearly politic related to tourism industry until first developing plan and also in the private district due to didn't clear politics and laws, there wasn't tendency to make resident and reception centers and plants; but in the course of politics of first, second and third developing plans, tourism district is benefited from special position in planning country and people up to become interested in the investment within making and developing resident and reception plants.

\section{Research Method}

This research is a survey using questionnaires. Features of rural services is considered as the independent variables and tourist's satisfaction as the dependent variable. In Order to Measure Tourists' Satisfaction of Tourism services, a questionnaire including 25 questions was completed by a sample of 384 tourists who had Visited Rural areas of Neyshabour in the Second three Months of 1392 and the Spring of 1393. For data analysis and drawing conclusions single sample T-test and correlation were used.

The study area is Neyshabour which according to the last country divisions of Iran is in Khorasan Razavi and has 4 sections, 7 cities, 13 towns and 975 villages. The city is 14/6763 Km square. Sections are: The Central section with Neyshabour as the center, Zebarkhan section with Ghadamgaah as the Center; Sarvelayat Section with Chekeneh as The Center And Miaan Jolgeh Section with Eshgh Abad as the Center (Iran Statistics Center:139 0). 28 villages were identified as tourist attractions from among which 14were studied as the sample: Boujan, Baqi, Shadmehrak/Mehraabaad, Miraabaad, Foushanjan, Dizbaad Oliya, Gerineh, Boujmehran, Es-haaghaabaad, Fadisheh, Kaleydar, Barzenon, Barfriz and Golbooye Paeen.

\section{Data analysis}

A - Examining the effect of rural facilities and services on tourists' satisfaction.

The level of rural tourists' satisfaction of facilities and services available was measured based on multiple indicators and the results are shown in Table 1. As can be seen rural areas of Neyshabour do not enjoy facilities and services. According to the tourists' opinion, environmental and health situation of the area is poor, accessing facilities and common living needs is not so easy, tourism services do not have diversity, tourists are not provided with enough information about the areas with tourist attraction. The tourists were not satisfied with the management asked for improvement of the administration of social security in these areas. Consequently tourists stay in these areas solely for a couple of hours. Calculations indicate the mean of satisfaction with facilities and services in the villages $2 / 50$, that is less than average. 
Table 1: Distribution of respondentson the level of satisfaction with rural facilities and services

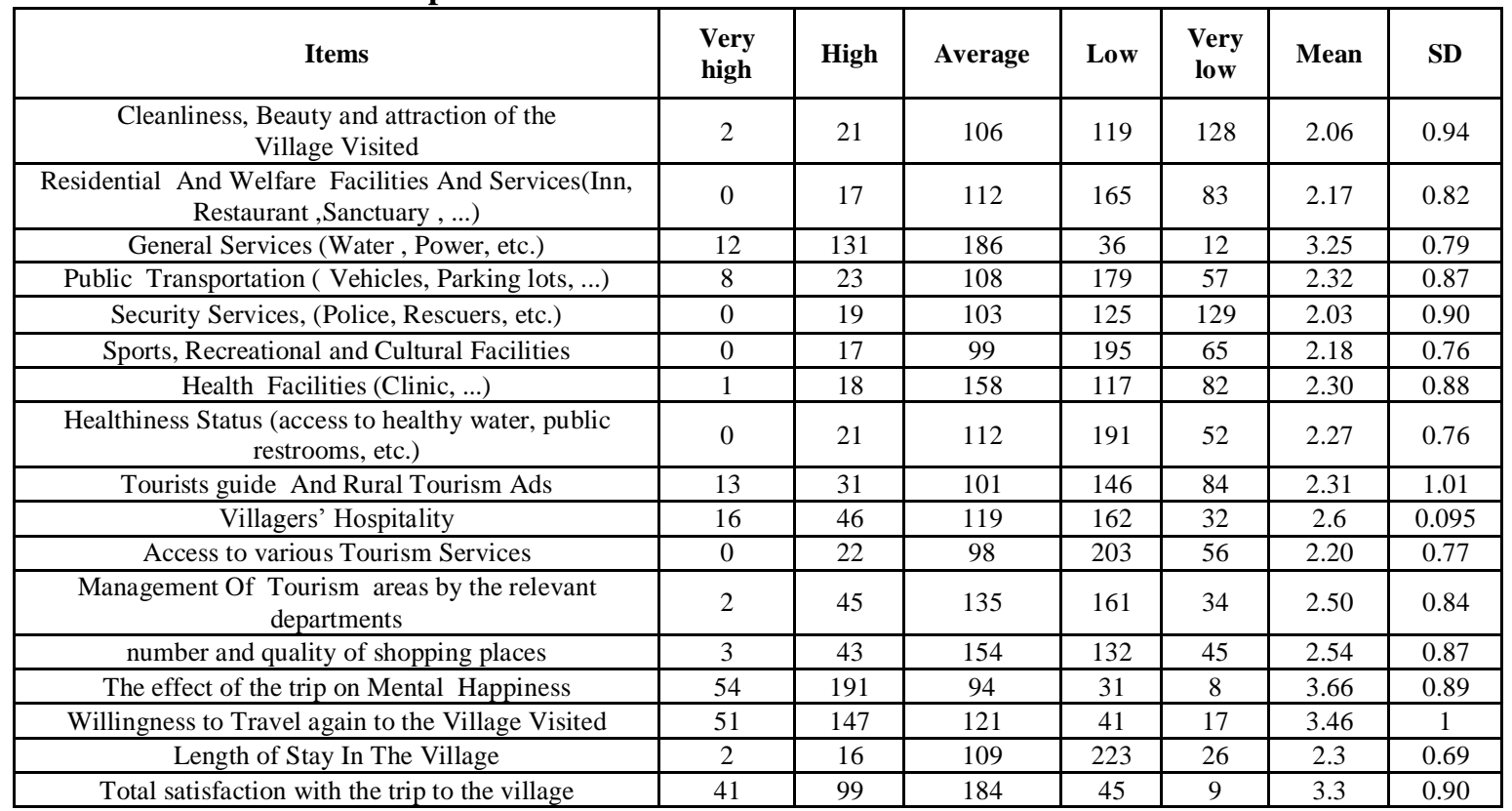

B - The relationship between tourism development and rural environmental degradation

In order to assess the relationship between the level of rural tourism facilities and services and the level of tourist satisfaction Pearson correlation test was used since measurement level of both variables is distance distance. The significance level ( $\mathrm{Sig})$ is 0.000 and less than the desired consistency $(0 / 01)$, therefore, $\mathrm{H}_{0}$ hypothesis is rejected and the relationship between the two variables is confirmed. Also the correlation is0/598, which indicates a high degree of correlation. Thus, the hypothesis that assumed a relationship between the level of rural services and facilities and tourist satisfaction is confirmed. Table 2 shows the results of this test.

Table 2- Pearson test (relationship between tourist facilities and tourist satisfaction)

\begin{tabular}{|c|c|c|c|c|}
\hline Type of test & Number of samples & Correlation & Significance Level & Desired consistency \\
\hline Pearson & 384 & $0 / 598$ & 0.000 & $0 / 01$ \\
\hline
\end{tabular}

\section{Source: author's calculations}

According to Table 3 Coefficient of determination between the two variables (status of satisfaction and facilities and services for tourists) shows that 35 Percent of changes in the level of tourists' satisfaction is due to changes in the level of rural facilities. The level of satisfaction will increase with tourism-related facilities improvement.

Table 3- Regression analysis

(the relationship between tourism facilities and services and tourists' satisfaction)

\begin{tabular}{|c|c|c|c|}
\hline Significance level & $\begin{array}{c}\text { Adjusted coefficient of } \\
\text { determination }\end{array}$ & $\mathrm{R}^{2}$ & The correlation coefficient (R) \\
\hline 0.000 & $0 / 354$ & $0 / 357$ & $0 / 598$ \\
\hline
\end{tabular}

\section{Source: author's calculations}

\section{Conclusions And Suggestions}

The results obtained in this study show that:

Rural features and services are not in a good level and this shortage is one of the factors preventing growth and development of tourism. Despite the relatively high number of tourists in rural regions, the effect of tourism on the economic section of these towns has not been significant due to low stay time and short trips of some hours only, low level of rural features and services, and low investment in rural tourism. Despite the various shortcomings in the level of towns' features and services, tourists satisfaction was relatively high with travelling to these regionswith tourist attractions which is due to strong natural and religious and historical attractions in these areas, covering the shortcomings. Obviously, with appropriate planning and investment and optimized use of these regions rural tourism will grow significantly. 
Relevant agencies more attention to tourism attractions in rural areas, explaining to the villagers, advertising, higher use of private sector investment, funding to build infrastructure and providing basic facilitiesfor the tourists can be a step in increasing the tourists' satisfaction and rural tourism development.

\section{References}

[1] Abraham, H., Roshandel, T. (2004) FactorsMvsrdrgrdshgryonunderstandingtourists' expectations gap analysismodel(Case study: TourismAreaSareynWiki) Business Management, No. 8.

[2] Firoozabadi, A., I. Jajarm, H. (2012) Villagerssatisfactionfactors related tothe two whichfunction(sample villages inQazvin province) RuralStudies, Vol III,Issue1. Madhoushi, M.(2003) Assessingbarriers tothe development ofthe tourism industry inthe province, Journal of BusinessResearch, No. 28 .

Statistical Center of Iran, 2013.

[3] J Clark, W.A.V. and Dieleman,F.M. (1996); Households and Housing:choise and outcomes in the housing market , new Brunswick, center for urban policy Research.

[4] Kitchin , R., Blades, M. and Reginalal G., G. (2002)."Relation between. Psychology and geography",Urban Studies , No 10

[5] Rezvani, M. (2011) Developmentof rural tourism, sustainable tourismapproach, Tehran University Press. Radial, AS, Moses,Citizen, C.(2011) levelof the cityin termsoftourisminfrastructureusingTopsisandAHp,urbanand regionalstudies, numberten.

[6] Seteriades, M(2002) Turism and Environment in Rural,Available on the Website : wwww.fund.Acbe/prelude. 